
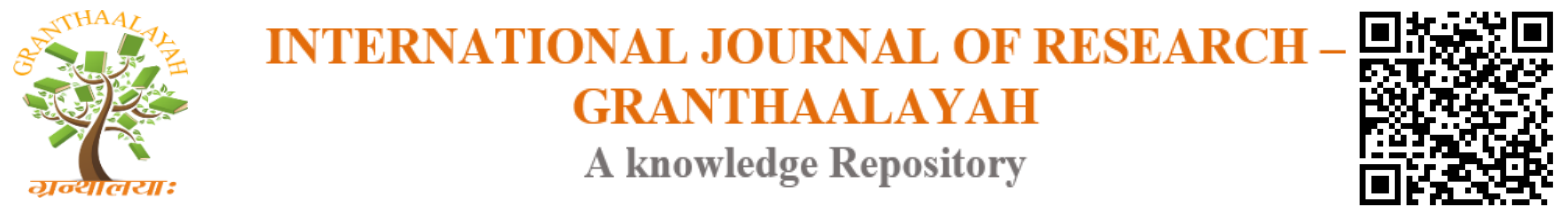

Management

\title{
AN EMPIRICAL STUDY ON AWARENESS AND CONSUMPTION PATTERN OF ORGANIC FOOD IN BENGALURU CITY, THE IT CAPITAL OF INDIA: AN ANALYSIS WITH RESPECT TO DIFFERENT DEMOGRAPHIC FACTORS AND AVAILABILITY OF ORGANIC FOOD PRODUCTS IN BENGALURU
}

\author{
Anwesha Chattopadhyay ${ }^{* 1}$, Priyanka Khanzode *2 \\ ${ }^{* 1}$ Ph.D., Research Scholar, Department of Statistics, University of Calcutta, India \\ ${ }^{*}$ Ph.D., Research Scholar, Department of Commerce and Management, ISBR B School, \\ University of Mysore, India
}

\begin{abstract}
Last 5 years have seen lots of changes in the consumption pattern of individuals with concerns rising constantly on the quality of climate conditions, individuals have become aware about change in climate, increasing pollution, deteriorating air quality, excessive use of chemicals in the farms, increase of carbon particles in environment and impact on population. Consumers now-a-days are very particular about the products they are consuming, Thus the concept of organic food product come into picture. This concept is gaining impetus in society especially after increase in health problems in individuals. It refers to using such food product which are eco-friendly and safe. The paper is a humble attempt to understand the level of awareness about organic food products in Bengaluru. This paper also aims at understanding the consumption pattern of individuals in Bengaluru. Statistical tools like ANOVA, Regression analysis, Chi-square tests and different charts are used to analyse the data obtained from a primary survey conducted in Bengaluru. On the basis of analysis done in the paper, it is concluded that the consumption has increased lately although more awareness should be created to make the consumption more popular among consumers.
\end{abstract}

Keywords: Fertilizers; Green Revolution; Organic Farming; Organic Food Products; Pesticides.

Cite This Article: Anwesha Chattopadhyay, and Priyanka Khanzode. (2019). "AN EMPIRICAL STUDY ON AWARENESS AND CONSUMPTION PATTERN OF ORGANIC FOOD IN BENGALURU CITY, THE IT CAPITAL OF INDIA: AN ANALYSIS WITH RESPECT TO DIFFERENT DEMOGRAPHIC FACTORS AND AVAILABILITY OF ORGANIC FOOD PRODUCTS IN BENGALURU." International Journal of Research - Granthaalayah, 7(1), 276-296. https://doi.org/10.29121/granthaalayah.v7.i1.2019.1055. 


\section{Introduction}

Organic products are earning lot of impetus in this world now-a-days. Organic products are mainly organic food, or products of cultivation that avoid the artificial and harmful agriculture enhancers like fertilizers or pesticides, insecticides etc. Organic farming has been a traditional way of farming in India. Those traditional ways once made India one of the most prosperous countries in the world. All the fertilizers and pesticides were made from plant and animal products which were absolutely non-toxic. But unfortunately, during 1950's and 1960's the combined effect of increasing population and several natural calamities led to scarcity of food and in order to fulfil that evergrowing needs of human beings, Green Revolution gained importance and took birth after 1963. As a result, government was forced to import food grains from foreign countries and drastically increase the food production in India. It has led to massive use of chemicals in the field to enhance productivity of crops as well as variety of crops in the market. In this regard there has being total ignorance towards use of natural manures to be used on field. Chemical ones replaced organic and natural fertilizers and pesticides. Hybrid seeds were introduced. Large amount of fields were brought under cultivation. As a result more fertilizers were required; factories were set up to fulfil this requirement. Hence land lost its fertility. As days passed by, pesticides became immune to the chemical pesticides, so there was a need of manufacturing stronger pesticides that were hazardous to human health. Green Revolution was a success in terms of gaining food security but it failed to attain nutritional sustainability.

The excess use of artificial fertilizers, chemical pesticides, food additives etc. has brought immense loss to human health in India. This is one of the main concerns right now. So, both consumers and farmers are noticed to shift back to organic farming. More people are moving towards use of organic products in their day-to-day life. Now a days we can find a range of organic products in the market like food and beverages, cosmetics, dairy products, electronics, automobiles, FMCG etc. Range and proximity to range of organic products in every field is increasing and have paved a way for organic market.

\section{Organic Farming}

Sustainable agriculture and organic farming go hand in hand. They both aim towards a healthy atmosphere for crops to yield. At the same time, it helps to keep health of soil in check. Sustainable agriculture can also be considered as a part of organic farming. Organic agriculture is "A unique production management system which promotes and enhances agro ecosystem, health, including biodiversity, biological cycles and soil biological activity, which is accompanied by using on farm agronomic, biological and mechanical methods in exclusion of all synthetic off-farm inputs" as per FAO. It has become very necessary now a days not only to improve public health condition, but also to reduce the loss incurred due to environmental pollution. It helps to restore food quality and food safety and also reduces agricultural costs. No wonder why the ancestors had led a healthy and blissful life.

According to Agricultural and Processed Food Products Export Development Authority (APEDA), India produced around 1.70 million MT (2017-18) of certified organic products which includes all varieties of food products namely Oil Seeds, Sugar cane, Cereals \& Millets, Cotton, Pulses, Medicinal Plants, Tea, Fruits, Spices, Dry Fruits, Vegetables, Coffee etc. The production is not limited to the edible sector but also produces organic cotton fiber, functional food products etc. 
Among different states Madhya Pradesh is the largest producer followed by Maharashtra, Karnataka, Uttar Pradesh and Rajasthan. In terms of commodities Oil seeds are the single largest category followed by Sugar crops, Cereals and Millets, Fiber crops, Pulses, Medicinal, Herbal and Aromatic plants and Spices and Condiments.

The total volume of export during 2017-18 was 4.58 lakh MT. The organic food export realization was around INR 3453.48 crore $(\mathbf{5 1 5 . 4 4}$ million USD). Organic products are exported to USA, European Union, Canada, Switzerland, Australia, Israel, South Korea, Vietnam, New Zealand, Japan etc.

In terms of export value realization Oilseeds (47.6\%) lead among the products followed by Cereals and millets (10.4\%), Plantation crop products such as Tea and Coffee (8.96\%), Dry fruits (8.88\%), Spices and condiments $(7.76 \%)$ and others.

\section{Benefits of Organic farming:}

- Helps to regulate Pollution: Pesticides, or other substances used to enhance farming capabilities often constitutes the run off from farms and join drinking water sources causing various environmental issues such as Bio magnification, Eutrophication etc. Since organic farming removes these factors from the quotient of agriculture, they also come with a guilt free conscience.

- Better health of individuals: When these pesticides or fertilizers enter water bodies, they often start accumulating in fishes, plants etc. When you consume these fishes, the accumulated toxins are released into ythe body bringing disastrous effects such as lead poisoning, Minamata Bay Disease etc. So we see indulging in organic farming can secure a better ticket to health.

- Less exposure to artificial medication: Livestock Rearing comes with injection of antibiotics to lengthen the lifespan of the animals and increase productivity. Organic farming does not involve this procedure; hence, we are safe from these kinds of antibiotics, which otherwise we would be exposed to from consuming meat, eggs or milk.

- Better Taste: Organic food almost always taste better due to their organic and environment-friendly way of practicing cultivation. Less use of preservatives and fertilizers go a long way in restoring the natural taste of these food products.

- Availability of Fresh Products: Say goodbye to cold storage food products, by embracing Organic Food. They do not include preservatives and hence are almost always sold fresh. This is why farmer's markets are such a popular phenomenon in different parts of the world like US, Japan etc.

- Reduction in agricultural cost: Organic farming paves the way to use of locally made pesticides as they are much cheaper than the factory-made pesticides which require expensive chemicals. In addition, the fertilizers made in organic manner are much cheaper than the synthetic ones. This can reduce the cost of farming and bring relief to the farmers.

\section{Ways to Do Organic Farming}

There are various ways of organic farming for production of organic food products such as compost, manure, green manure, and bone meal and places emphasis on techniques such as crop rotation and companion planting. Biological pest control, mixed cropping and the fostering of insect predators are enctheaged. In general, organic standards are designed to allow the use of 
naturally occurring substances while prohibiting or strictly limiting synthetic substances. Agnihotra Farming is also a part of Organic Farming. Few examples of organic product attained after applying Agnihotra farming are pulses, lentils, Chana daal, masoor daal, grapes, various vegetables like cauliflower, groundnuts, turmeric, wheat, tomato, cucumber, garlic, ginger etc. and positive results had been attained.

\section{Organic Market in India}

There are various Companies producing organic products in India. They are Organic Mandya, Mother earth, Madhav ashram trust, Art of Living, Farm 2 Kitchen, Big Basket, Pro-nature organic, Originnel Organic Food, Nature's hub, Nisraga Organic, ISKCON Organic Outlet, Karnataka Organic Farming centre and others.

\section{Literature Review}

Priya Soni, a noted researcher has stated in her research paper that, there is a positive attitude towards of customers towards buying organic food in India and is linked to believing that it is healthier, tastes better, and is better for the environment. K. Sundaresh \& Dr. S. Babu have given opinion that it is incidental that socio- economic variables are associated with consumer positive attitude towards organic foods. Family, self-decision and friends play a vital role in the purchase decision-making process of organic foods. The factors eco-friendly and chemical or pesticides free factor have a great impact on the decision-making process. According to K. Renugadevi \& Dr. M. Ramya Organic food product is been accepted as a nutritional food and helps to keep human healthy in spite of busy work schedule, stress and pollution. The short supply and premium price of organic products may disturb the growth of consumption rate. According to S. Suganya and Dr. S. Saravinth in their research concluded that it is evident that people's awareness towards organic products has increased considerably and they are willing to purchase the organic products if it is affordable and available. According to Brijesh Sivathanu. Consumers consider health as an important parameter and then they buy the product, also there are various factors impacting the preference including demographic characteristics of the consumers. As per study of Konda Kalyani "The system of organic agriculture, especially the system of organic food production, becomes more and more important factor of national and international economic system development. The importance of organic food marketing is conditioned by the fact that it enables producers for better understanding of customers' needs serving the purpose of better meeting their needs and it also enables consumers to realize better organic products supply. Today's society very excitedly welcomes these concepts and people are in a path to change their lifestyle, food habit. Still it is pity to know that where one group of people rushing up to change their whole lifestyle to organic there we can note that there is no pint-sized sift in their food habit for the other group. People still lack basic knowledge about organic food, clothing and so on. But High pricing for some organic product is out of reach of common man. Least variety creates dissatisfaction among the customer. Last but not the least is the lack of awareness of the organic products. So, it is prime time to buzz the alarm and make everyone alert about the upcoming danger of health issues and walk forward to create a healthy tomorrow for one \& all. According to Sathyendra Kumar AD, Dr. H. M. Chandrashekar consumer behavithe plays the major role while buying not only organic product any product. So, the organic food shops and product supply is limited but demand for it, is more. So, the farmers and also the government are thinking to improve or increase production of organic product as well as good packaging, quality and market system. It helps to 
improve the standard of living farmer and all it healthy to environment and all so it helps to government. The marketers of organic foods need to be innovative and dynamic in order to complete with the changing purchase behavithe in the Organic food products market among urban residents. Vishal Kumar Laheri, Purushottam Kumar Arya has stated that, the results of the survey suggested that there is a need for organizing many awareness programs by the government, marketers, and environmental agencies to educate consumers for using eco-friendly products, which are good for their health and at the same time safe for the environment. As per the results of the survey, the price and availability of the organic products are the prime barriers towards its purchase, so the marketers need to focus on such barriers for penetrating the market of organic products in India. Barriers of purchasing organic food products provided by the present study will offer guidelines to the marketers for understanding the attitude and preferences of consumers towards organic food products. According to Nayana Sharma and Dr. Ritu Singhvi their study also revealed the availability of the market can influence consumer's preferences and choices for purchasing organic food products. This paper thus provides vital information that there will be more demand of the organically grown food products in coming future, so it's high time for producer, traders, consumer and government itself to focus over the niche market of organic. Singh et al. studied organic cotton farming which helped in garment manufacture in Madhya Pradesh. According to his reports, $80 \%$ farmers shifted to organic farming due land quality improvement and at least $36 \%$ due to assured market. Sharma explained the factors determining consumer's acceptance and preference for food in general. Many factors combine and interact to make buying a complex process. Price was identified as an important factor; however it had some limitations on the consumer's choice. Factors like sensory attributes regional preference, age, sex, interest, motivation, discrimination and income also influenced food consumption. Shukla et al. conducted a survey to know the consumer response to green market opportunities. It was found that the customers were appraising the organic products on safety to nature and human health and that their brand awareness was generally low. Kubendran and Vanniarajan revealed that the change in consumption pattern is due to the changes in food habits. If income and urbanization increases among consumers the percentage of income spent on consumption increases. The urban consumers prefer mostly branded products compared to rural consumers. The most significant factors influencing buying decisions are accessibility, quality, regular supply, door delivery and the mode of payment.

\section{Objectives of the Research}

- To study the awareness of organic food in the market among people of Bengaluru.

- To study briefly the consumption pattern of the consumers in Bengaluru.

- To give an idea about factors affecting consumption of organic food by the consumers in Bengaluru.

\section{Research Methodology}

\section{Data}

Primary data had been collected from different locations of Bengaluru by means of structured questionnaire. The sample size is 105 . Convenient sampling has been conducted. 
Bengaluru or Bangalore is capital of Karnataka, a southern state in India. It is located in Deccan Plateau in southeastern Karnataka. It is the third largest city and fifth largest metropolitan city in India.

Bengaluru is a metropolitan and cosmopolitan city that comprises of people from different cultures, religions, castes, languages, occupations, income groups and different food preferences. It is IT hub of India. It is called Silicon Valley of India. It has numerous educational and financial institutes, also several organic food outlets along with potential buyers who can afford organic food products. It has also been found that there is an increasing demand for organic food products here.

Bengaluru is organic hub of India and has the highest sales of organic food product as well as the largest number of organic outlets growing at the rate of $35-40 \%$ per year.

\section{Statistical Tools Used}

- Microsoft Excel for the graphs and charts

- R for statistical tests, charts and calculations

\section{Statistical Techniques Used}

- Chi-square test.

- Proportion test

- ANOVA

- Descriptive analysis

- Regression analysis

\section{Analysis and Findings}

When the percentage of awareness of organic food products was calculated from the data, it was found to be very high. Almost $95 \%$ of the respondents had knowledge about organic food products irrespective of all the demographic factors as well as other factors.

\section{Analysis on Awareness and different demographic factors}

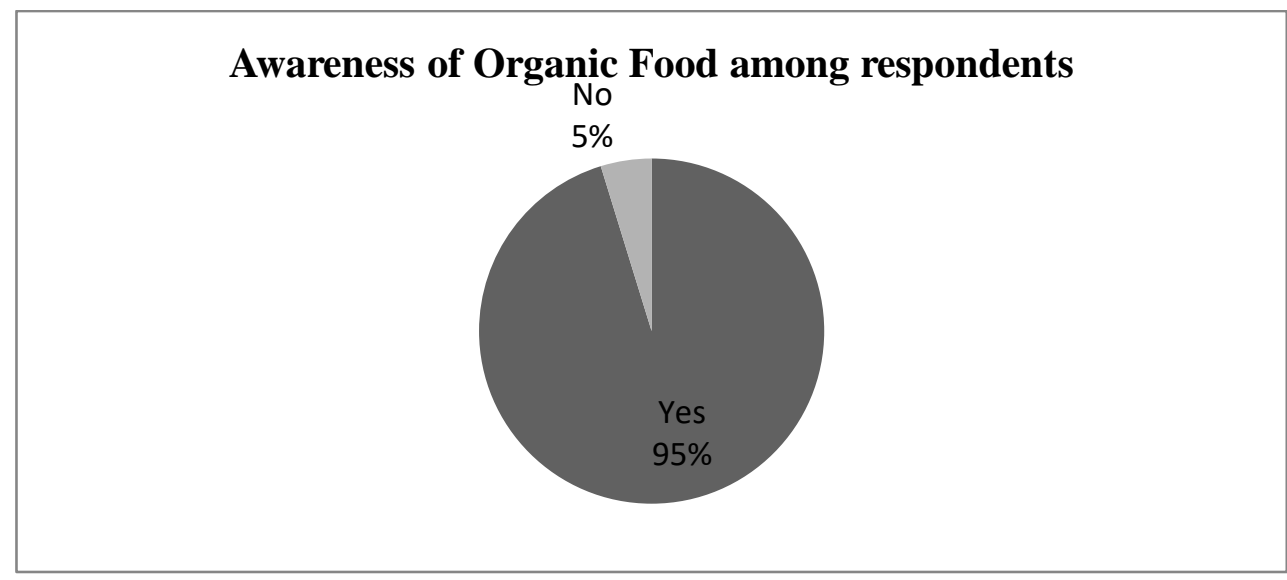

Figure 1: Awareness of organic food 
Now the demographic factors like age, sex, number of family members, marital status and educational qualification are considered. Since the data collection is done in Bangalore and there are many people staying in Bangalore are from different states and cities of India for job purposes, so another factor has been taken into consideration. That factor is defined as native and hence got two outcomes viz. Bangalore and outside.

The first demographic factor is Age. The age-group is divided by an interval of 5 years and observed that the number of respondents distributed throughout all the age-groups is not equal.

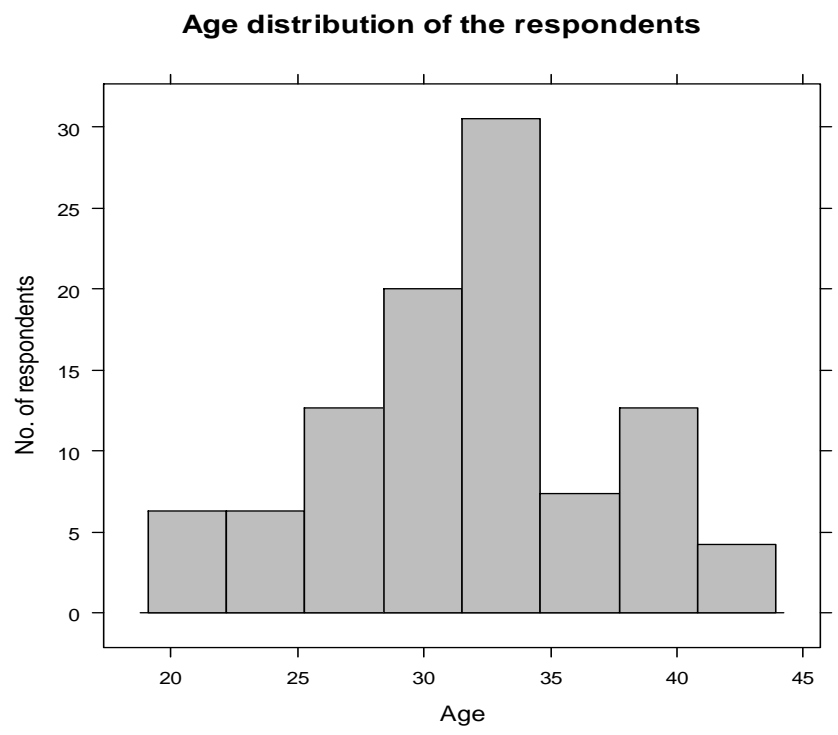

Figure 2: Age distribution

The interval 25-35 years has maximum number of respondents, while the number is lesser in the edges. So the proportion of respondents aware about organic food in all the age groups is taken into account. The age distribution has a bell-shaped curve and hence is normal. To be more sure a normality test is done in software and get $\mathrm{p}$-value $=0.053>0.05$ and conclude that the age distribution of the population from where the sample is drawn is normal.

Table 1: Proportion of people of different age-groups aware about organic food.

\begin{tabular}{|l|l|l|l|}
\hline $\begin{array}{l}\text { Age- } \\
\text { group }\end{array}$ & $\begin{array}{l}\text { Aware about organic } \\
\text { food }\end{array}$ & $\begin{array}{l}\text { Total no. of } \\
\text { respondents }\end{array}$ & $\begin{array}{l}\text { Proportion of } \\
\text { awareness }\end{array}$ \\
\hline $\mathbf{2 0 - 2 4}$ & 12 & 13 & 0.923077 \\
\hline $\mathbf{2 5 - 2 9}$ & 25 & 26 & 0.961538 \\
\hline $\mathbf{3 0 - 3 4}$ & 37 & 39 & 0.948718 \\
\hline $\mathbf{3 5 - 3 9}$ & 17 & 17 & 1 \\
\hline $\mathbf{4 0 - 4 4}$ & 6 & 7 & 0.857143 \\
\hline $\mathbf{4 5 - 4 9}$ & 2 & 2 & 1 \\
\hline$>\mathbf{5 0}$ & 1 & 1 & 1 \\
\hline Total: & 100 & 105 & 0.952381 \\
\hline
\end{tabular}


Next, a proportion test is conducted to find out whether it can be suggested that the proportions of knowledge of organic food products are equal in all age-groups. Thus, the null hypothesis is $\mathrm{H}_{1}$ : The proportions are equal against $\mathrm{H}_{1}{ }^{\prime}$ : At least one proportion is not equal.

The p-value $=0.8448>0.05$. Hence the null hypothesis is accepted and hence can be concluded that the proportions in all the age groups are equal for the population from where the sample has been drawn. In addition, it has been already found out that the age-distribution is normal.

Mean cannot be calculated here as there is open-end class. So the median is calculated as an average and it is equal to 31.26 years. It means that the average age of respondents knowing about organic food in 31.26 years.

Next demographic variable to be considered is Sex. In the sample the number of male and female respondents are not equal.

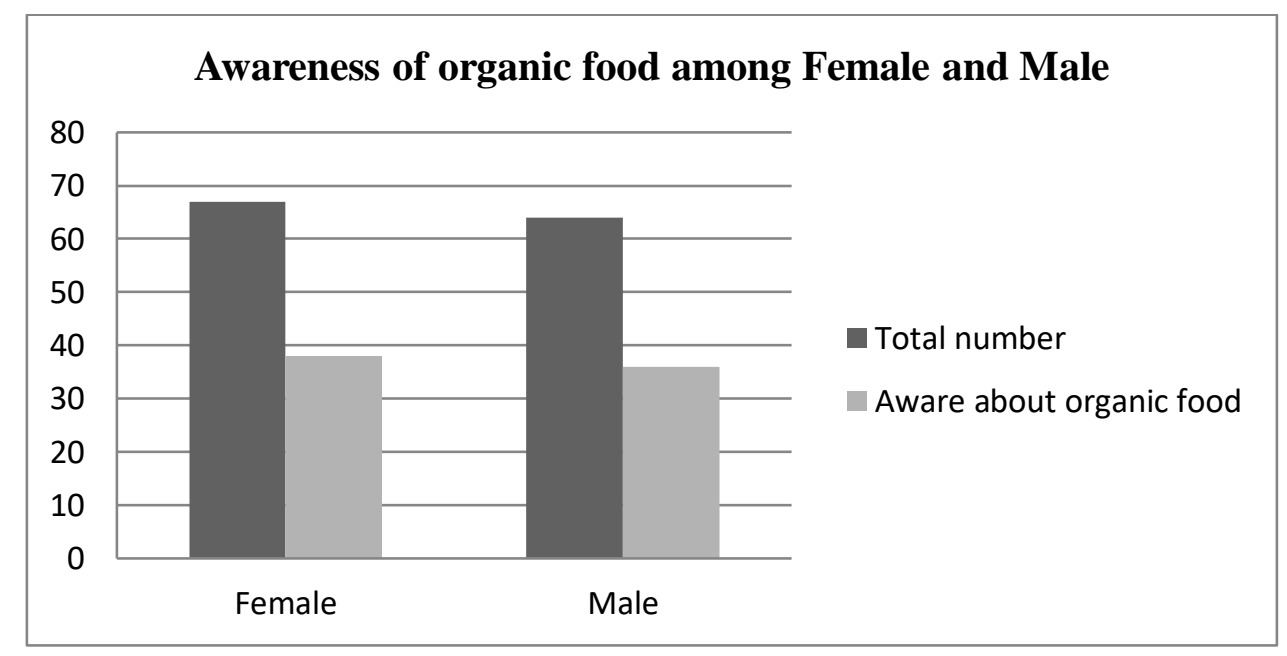

Figure 3: Awareness of organic food sex-wise

The diagram reveals that number of female respondents in the data is much more than that of male respondents. Hence a proportion test I done for the two groups. The null hypothesis is $\mathrm{H}_{2}$ : The proportions of respondents aware about organic food for both male and female are equal against the alternative hypothesis $\mathrm{H}_{2}$ ': The proportions are not equal.

The p-value is very high which is $0.9>0.05$. Hence null hypothesis is accepted and concluded that the proportions are equal for the population.

The Table 2 represents the number of aware respondents considered age-wise and sex-wise. Hence a two-way table is obtained.

Table 2: Awareness of organic food according to age and sex together

\begin{tabular}{|l|l|l|l|l|}
\hline Age- group & Sex & Female & Male & Total \\
\hline $\mathbf{2 0 - 2 4}$ & & 7 & 5 & 12 \\
\hline $\mathbf{2 5 - 2 9}$ & & 21 & 4 & 25 \\
\hline $\mathbf{3 0 - 3 4}$ & & 18 & 19 & 37 \\
\hline
\end{tabular}




\begin{tabular}{|l|l|l|l|}
\hline $\mathbf{3 5 - 3 9}$ & 11 & 6 & 17 \\
\hline $\mathbf{4 0 - 4 4}$ & 4 & 2 & 6 \\
\hline $\mathbf{4 5 - 4 9}$ & 2 & 0 & 2 \\
\hline$>\mathbf{5 0}$ & 1 & 0 & 1 \\
\hline Total: & 64 & 36 & 100 \\
\hline
\end{tabular}

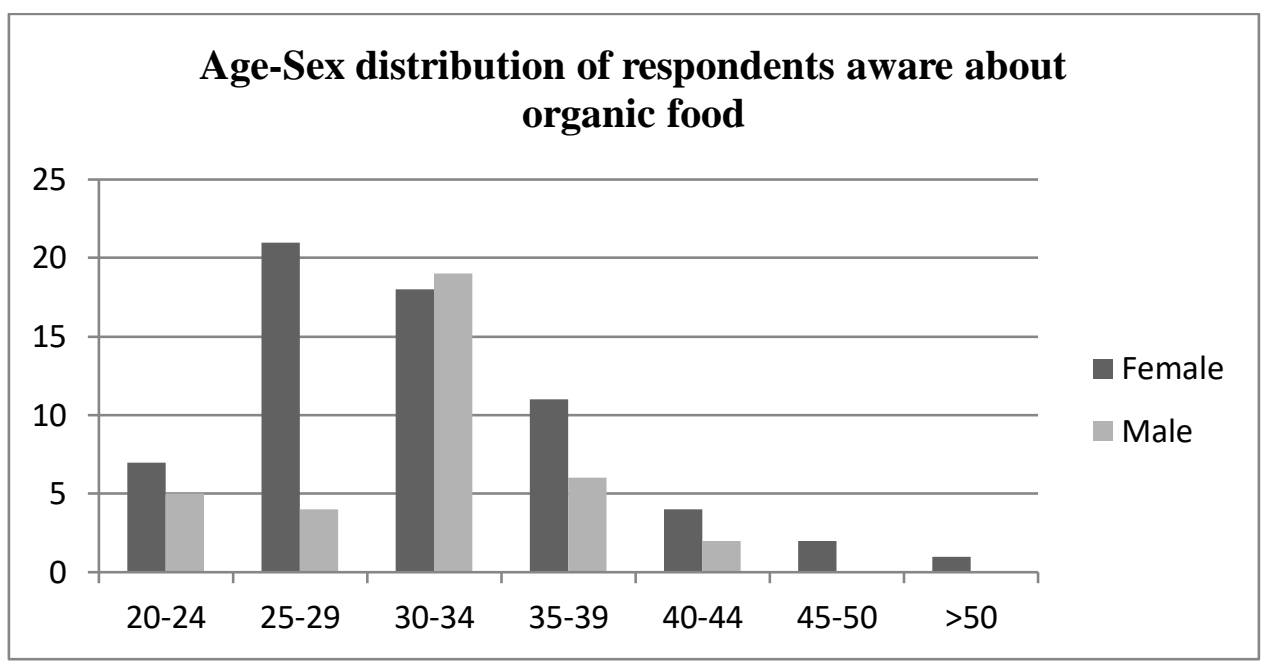

Figure 4: Age-sex distribution according to awareness of organic food

A two-way ANOVA test is conducted where the null hypothesis $\mathrm{H}_{3}$ : The means in all age-groups are equal and means for male and female are equal against the alternative hypothesis $\mathrm{H}_{3}$ ': At least one mean in the age groups are not equal and Means of female and male are not equal.

The ANOVA table thus obtained is Table 3:

Table 3: Two-way ANOVA table for age and sex

\begin{tabular}{|l|l|l|l|l|l|l|}
\hline ANOVA & & & & & & \\
\hline Sthece of Variation & $\boldsymbol{S S}$ & $\boldsymbol{D F}$ & $\boldsymbol{M S}$ & $\boldsymbol{F}$ & $\boldsymbol{P}$-value & $\boldsymbol{F}$ critical \\
\hline Rows & 519.7143 & 6 & 86.61905 & 4.812169 & 0.038692 & 4.283866 \\
\hline Columns & 56 & 1 & 56 & 3.111111 & 0.128213 & 5.987378 \\
\hline Error & 108 & 6 & 18 & & & \\
\hline Total & 683.7143 & 13 & & & & \\
\hline
\end{tabular}

P-value for rows i.e for age is $0.038692<0.05$ which implies rejection of null hypothesis for the age-groups. It can be said that at least one mean is not equal to the other means. On the other hand p-value for columns i.e for sex is $0.128213>0.05$. This suggests the acceptance of the null hypothesis for sex. It can be concluded that the means for both male and female respondents are equal. It means that sex has no effect on the awareness of organic food products but age has.

Next the marital status is taken as the next demographic variable. Two options are there, namely married and single. 


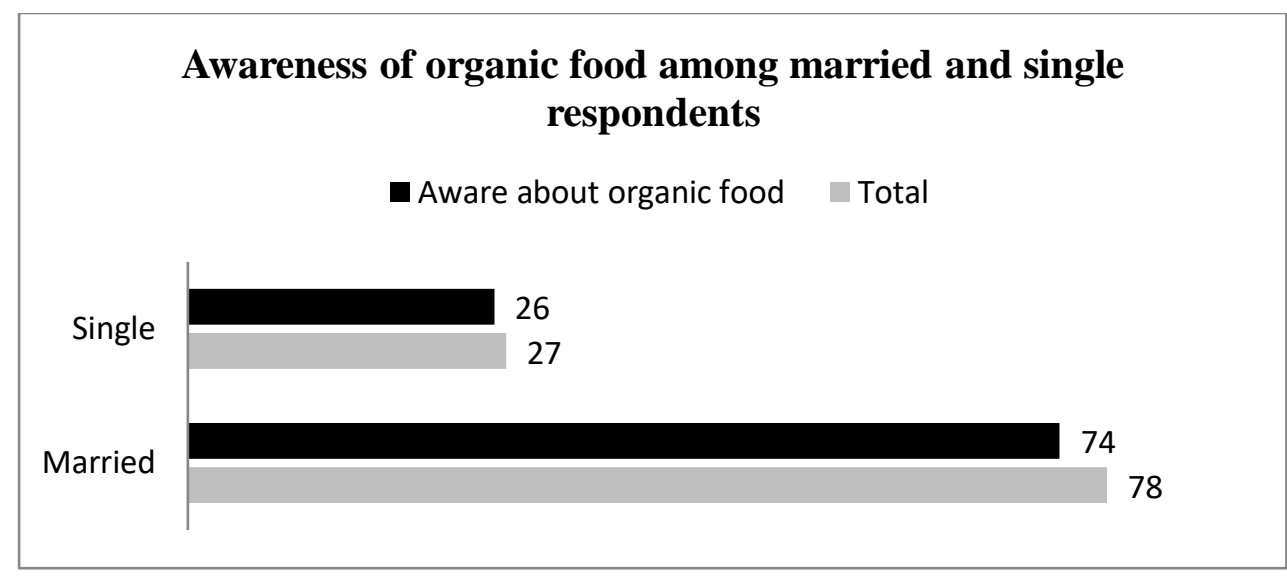

Figure 5: Awareness of organic food according to marital status

In the data number of married people is high in numbers, so the proportion test is performed for the two groups. The null hypothesis is stated as $\mathrm{H}_{4}$ : The proportions of respondents aware about organic food for both married and single are equal against the alternative hypothesis $\mathrm{H}_{4}$ ': The proportions are not equal.

The $\mathrm{p}$-value is very high which is $0.9>0.05$. Hence null hypothesis is accepted and concluded that the proportions are equal for the population.

Educational qualification is yet another key factor for awareness of organic food. Five levels are mentioned here, namely Doctorate, PG, Graduation, Higher Secondary, Secondary but none of the respondents had been recorded as Higher secondary. So finally, 4 levels are considered.

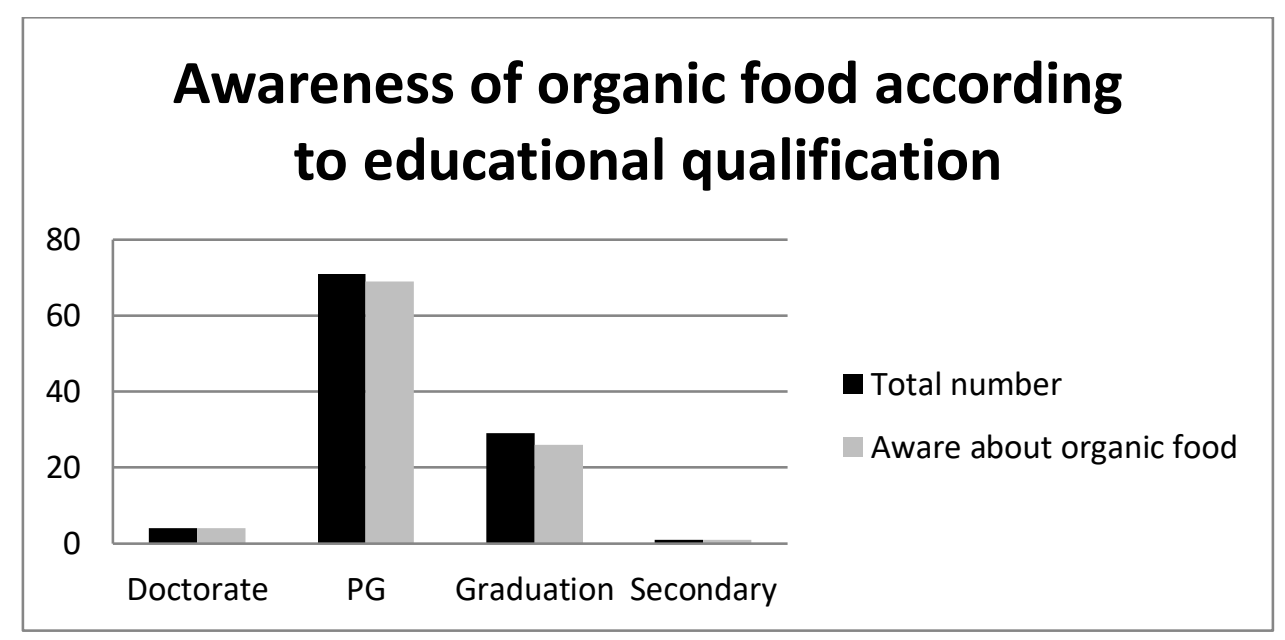

Figure 6: Awareness of organic food according to educational qualification

Maximum of the respondents are post-graduates. Hence the proportion test is performed. The null hypothesis is stated as $\mathrm{H}_{5}$ : The proportions of respondents aware about organic food for all levels of education are equal against the alternative hypothesis $\mathrm{H}_{5}$ ': The proportions are not equal.

The $\mathrm{p}$-value is very high which is $0.4177>0.05$. Hence null hypothesis is accepted and concluded that the proportions are equal for the population. 
Another demographic factor considered in this study is native. Here it has been considered whether people staying in Bangalore are originally from Bangalore or from some other place. Reason for considering this factor is the fact that many people from outside come and stay in Bangalore for jobs.

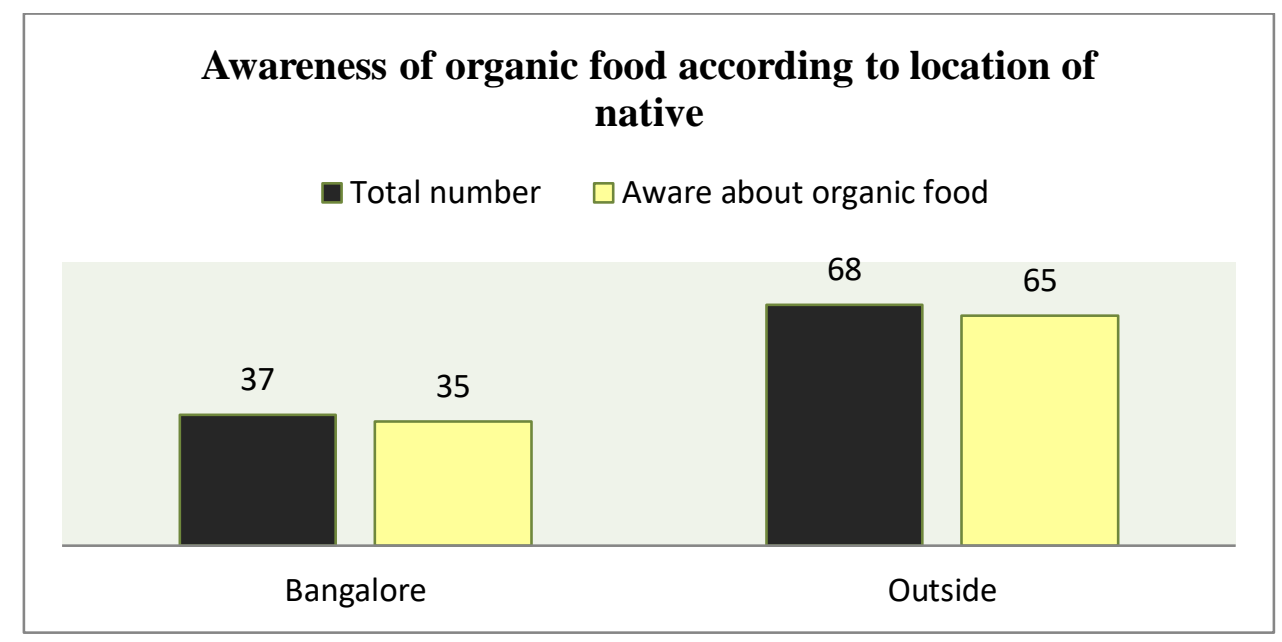

Figure 7: Awareness of organic food according to location of native

In this case also the proportion test is performed. The null hypothesis is stated as $\mathrm{H}_{6}$ : The proportions of respondents aware about organic food for the location of natives are equal against the alternative hypothesis $\mathrm{H}_{6}$ ': The proportions are not equal.

The p-value is very high which is $0.9>0.05$. Hence null hypothesis is accepted and concluded that the proportions are equal for the population.

Next Chi-square test of independence is conducted for all the demographic factors to test whether the awareness of organic food is independent of the demographic factors. Hence the following hypotheses are stated.

$\mathrm{H}_{01}$ : Awareness is independent of age-groups $\mathrm{H}_{11}$ : it is not independent.

$\mathrm{H}_{02}$ : Awareness is independent of sex $\mathrm{H}_{12}$ : it is not independent.

$\mathrm{H}_{03}$ : Awareness is independent of education $\mathrm{H}_{13}$ : it is not independent.

$\mathrm{H}_{04}$ : Awareness is independent of marital status $\mathrm{H}_{14}$ : it is not independent.

$\mathrm{H}_{05}$ : Awareness is independent of native location $\mathrm{H}_{15}$ : it is not independent.

Table 4: Chi-square test for different demographic factors.

\begin{tabular}{|l|l|l|l|l|l|}
\hline Demographic Factors & Chi-square value & D.F. & P-value & Comparison & Decision \\
\hline Age & 2.706 & 6 & 0.8448 & $>0.05$ & Accept \\
\hline Sex & $4.9 \times 10^{-31}$ & 1 & 0.9 & $>0.05$ & Accept \\
\hline Education & 2.835 & 3 & 0.4177 & $>0.05$ & Accept \\
\hline Marital Status & $1.8 \times 10^{-30}$ & 1 & 0.9 & $>0.05$ & Accept \\
\hline Place & $3.1 \times 10^{-31}$ & 1 & 0.9 & $>0.05$ & Accept \\
\hline
\end{tabular}

It is found that the awareness about organic food is independent of all the demographic factors. 
People were asked whether they are aware about advantages of organic food, $90 \%$ of respondents gave positive response while only $10 \%$ said no.

\section{Analysis on awareness of advantages of organic food}

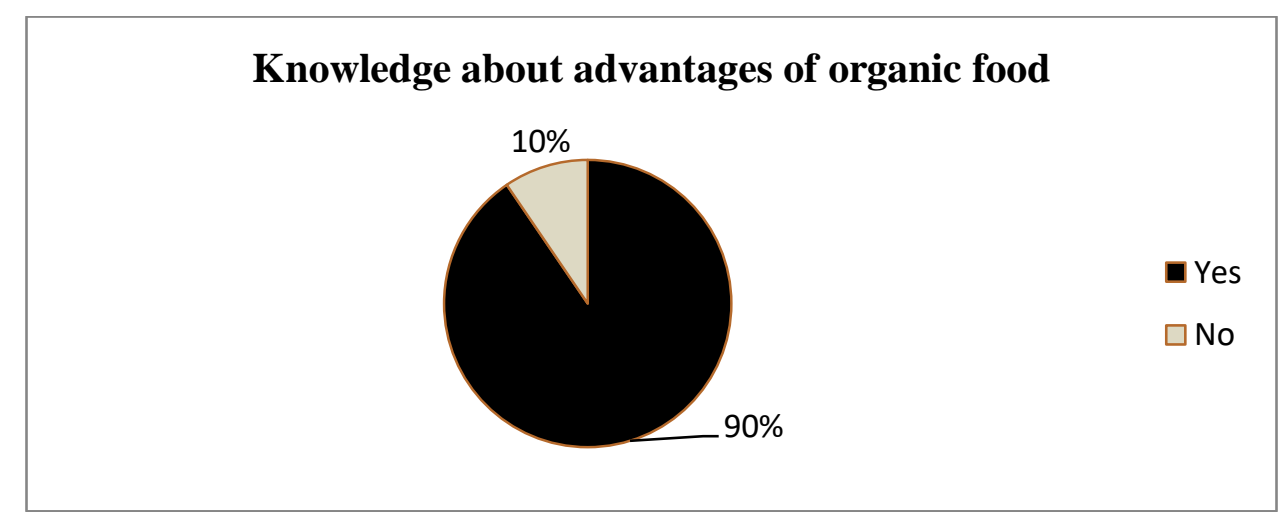

Figure 8: Awareness about advantage of organic food

Next respondents were asked about the advantages, maximum people said it is a great option of a healthy lifestyle which is very important these days. Also people are aware that pesticides are not used in such kind of food, so it is less harmful and toxic. Some people are also aware about the sustainable development of the environment as organic farming reduces environmental pollution.

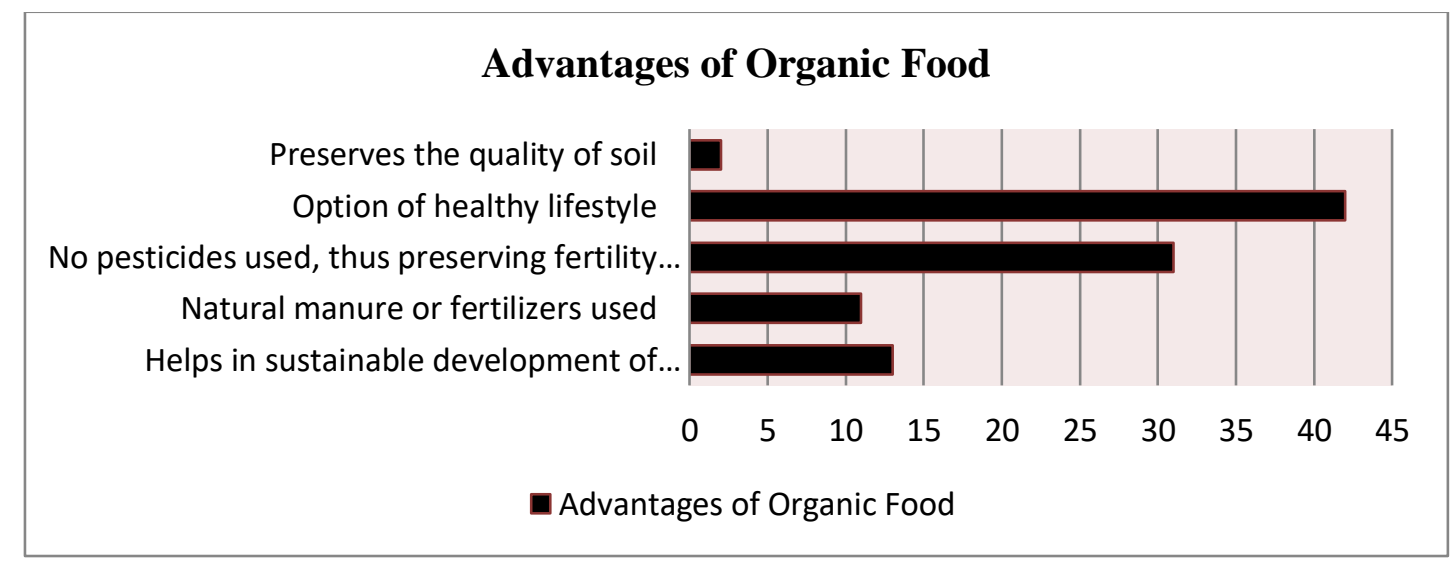

Figure 9: Advantages of organic food

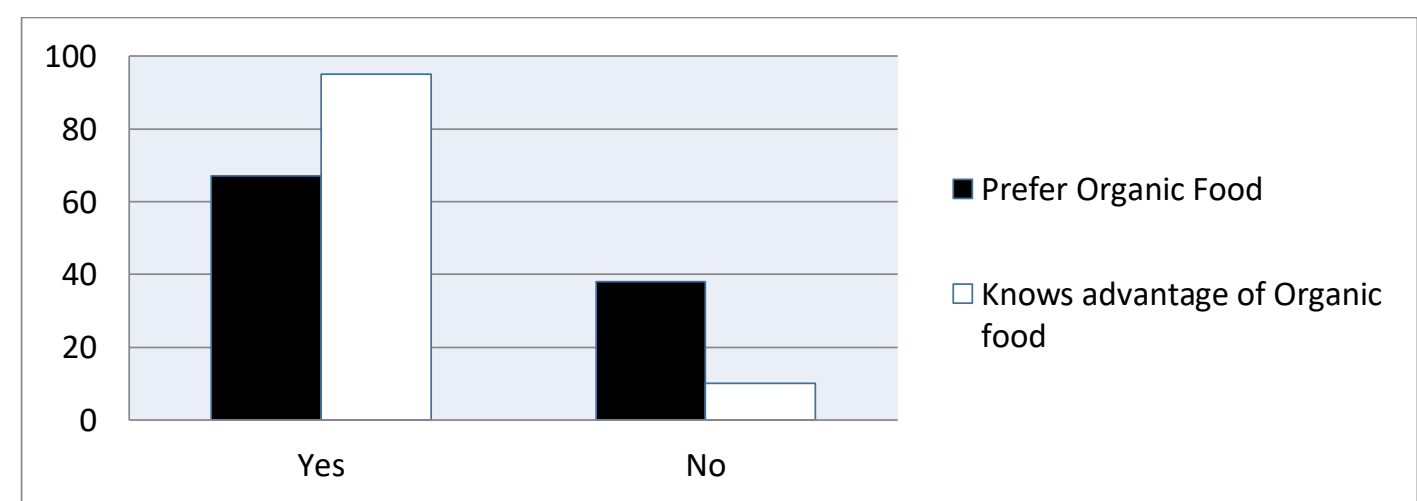

Figure 10: Number of people having knowledge about organic food and prefering it 
A peculiar pattern is observed when the data regarding number of people having knowledge about organic food and prefering it has been plotted. It can be assumed that those who have knowledge of advantage of organic food will prefer to consume it and those who do not have any knowledge will not prefer. But in this case it was found that only $70.5 \%$ of respondents having knowledge, prefer organic food. A chi-square test of independence is performed between these two factors. The hypothesis is stated as $\mathrm{H}_{06}$ : Knowledge about advantage of organic food and preferance are independent against the alternative hypothesis $\mathrm{H}_{16}$ : They are not independent. The $\mathrm{p}$-value $<0.05$ suggests that having knowledge and prefering organic food are not independent of each other.

All previous discussions revolved around the awareness of organic food among the respondents, also about its advantage and its relation to the choice of food. Next the important point to discuss is about the consumption and factors affecting consumption of organic food among the consumers.

\section{Analysis on consumption pattern of consumers in accordance to their income and availability of organic food}

\section{Pie-chart showing percentage of consumption of organic and non-organic food}
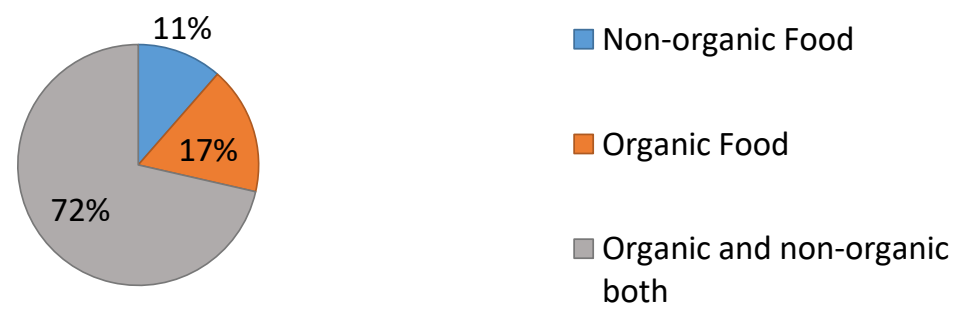

Figure 11: Consumption of organic and non-organic food

According to the data, only $11 \%$ of the respondents solely consume non-organic food. $17 \%$ people consume only organic food products which is low, while $72 \%$ people consume both organic and non-organic food. So it is very clear that maximum people do not depend solely on organic food on daily basis.

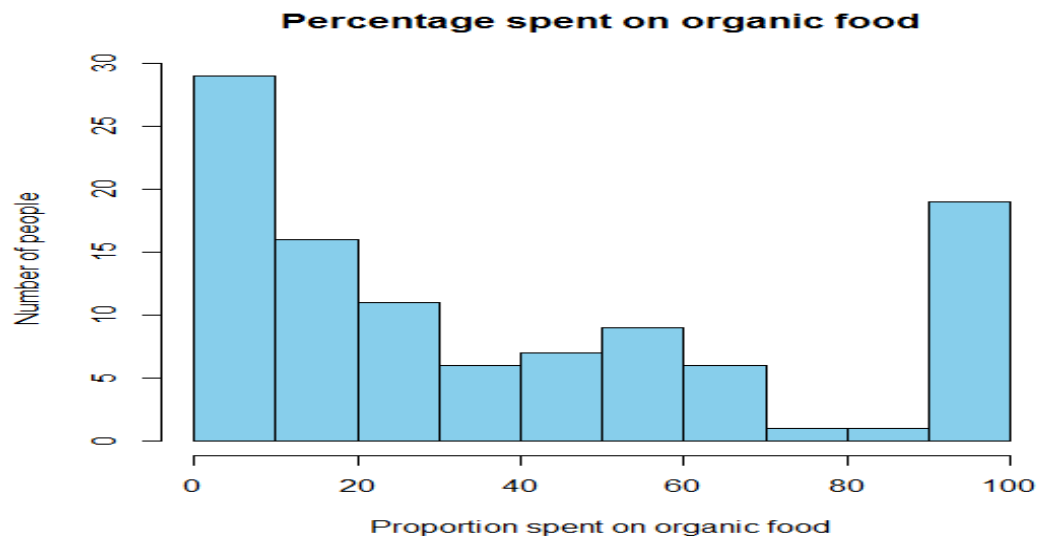

Figure 12: Histogram showing percentage of total spending on food spent on organic food 
In figure 12, $\mathrm{x}$-axis denotes the percentage of total spending on food spent on organic food and $\mathrm{y}$ denotes the number of respondents falling in each group. It is observed that maximum number of respondents spend $0-10 \%$ of their total spending on food in buying organic food products while second highest number of people spend $90-100 \%$. The mean is calculated which is equal to $27.42 \%$, that means people spend average of $27.42 \%$ of their total spending on food in consuming organic food products every month. This figure is very low. The standard deviation is equal to $27.2 \%$. This high value of S.D. suggests that although the mean is less, the variation of the percentage is not less.

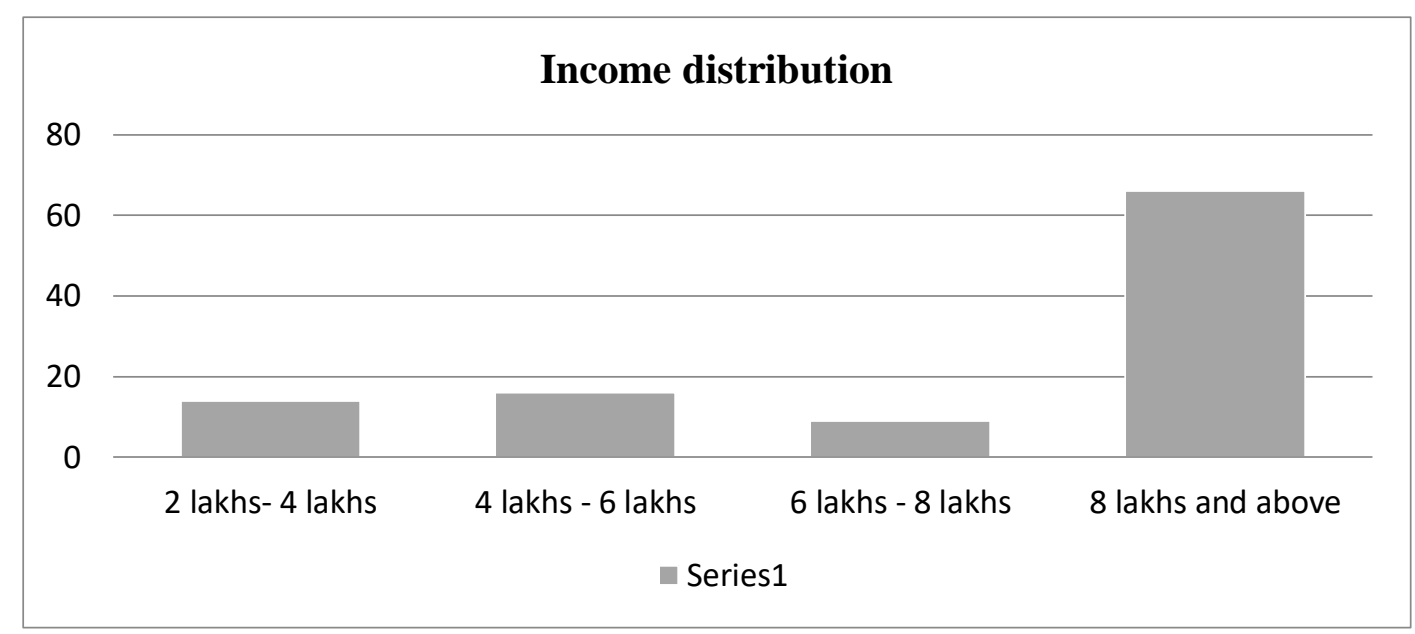

Figure 13: Income distribution of the data

Figure 13 shows that in the data, maximum number of respondents belong to the last group i.e. 8 lakhs and above. The consumption pattern of the consumers depending on the income groups is testes in Figure 14.

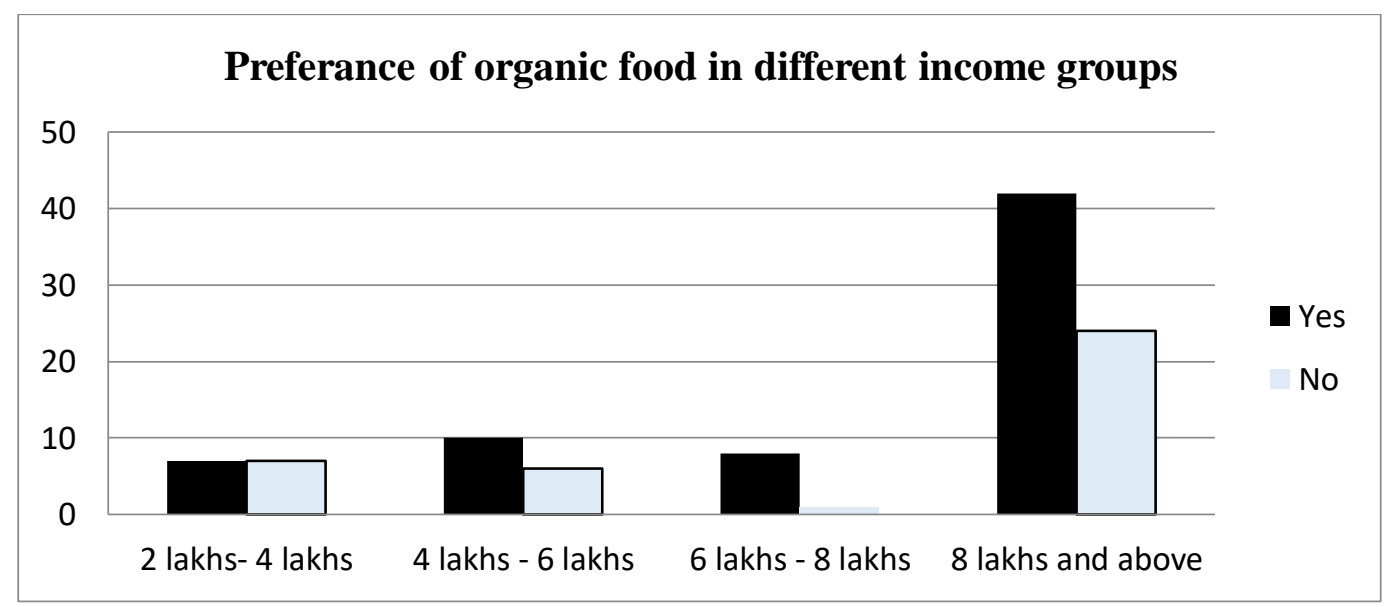

Figure 14: Preferance of organic food in different income groups

Since the income distribution is not unifrormly distributed, chi-square test of independence is performed stating the null hypothesis $\mathrm{H}_{07}$ : Preferance of organic food is independent of the income groups against the alternative hypothesis $\mathrm{H}_{17}$ : They are not independent. The $\mathrm{p}$-value $=0.3055$ > 0.05 concludes that the preferance is independent of the income levels. 


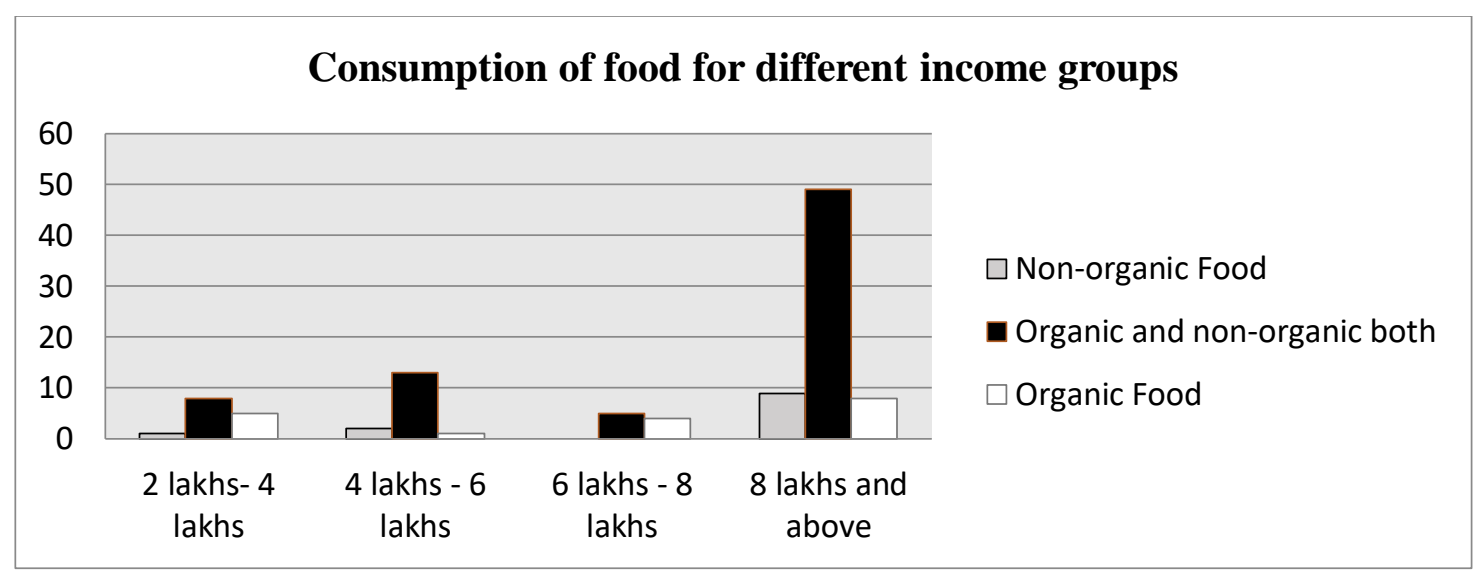

Figure 15: Consumption of organic and inorganic food for different income groups

A chi-square test of independence is done stating the null hypothesis $\mathrm{H}_{08}$ : consumption of different types of food is independent of the income groups against the alternative hypothesis $\mathrm{H}_{18}$ : They are not independent. The $\mathrm{p}$-value $=0.0777>0.05$ concludes that the consumption is independent of the income levels.

A two-way ANOVA test is conducted where the null hypothesis $\mathrm{H}_{09}$ : The means in all incomegroups are equal and means for all types of food are equal against the alternative hypothesis $\mathrm{H}_{19}$ : At least one mean in the income-groups are not equal and means of all types of food consumption are not equal.

The ANOVA table is represented as Table 5:

Table 5: Two-way ANOVA table for income and consumption

\begin{tabular}{|l|l|l|l|l|l|l|}
\hline ANOVA & & & & & & \\
\hline $\begin{array}{l}\text { Sthece of } \\
\text { Variation }\end{array}$ & $\boldsymbol{S S}$ & $\boldsymbol{d} \boldsymbol{M}$ & $\boldsymbol{M S}$ & $\boldsymbol{F}$ & P-value & F critical \\
\hline Rows & 710.9167 & 3 & 236.9722 & 2.305053 & 0.176642 & 4.757063 \\
\hline Columns & 604.5 & 2 & 302.25 & 2.940016 & 0.128825 & 5.143253 \\
\hline Error & 616.8333 & 6 & 102.8056 & & & \\
\hline Total & 1932.25 & 11 & & & & \\
\hline
\end{tabular}

P-value for rows i.e for income is $0.176652>0.05$ which implies that null hypothesis is accepted for the income-groups. It can be said that means are equal for all income groups. On the other hand p-value for columns i.e for consumption is $0.128825>0.05$. This suggests null hypothesis is accepted for consumption. It can be concluded that the means for different types of consumption are equal. It means both income and consumption are insignificant for each other. 


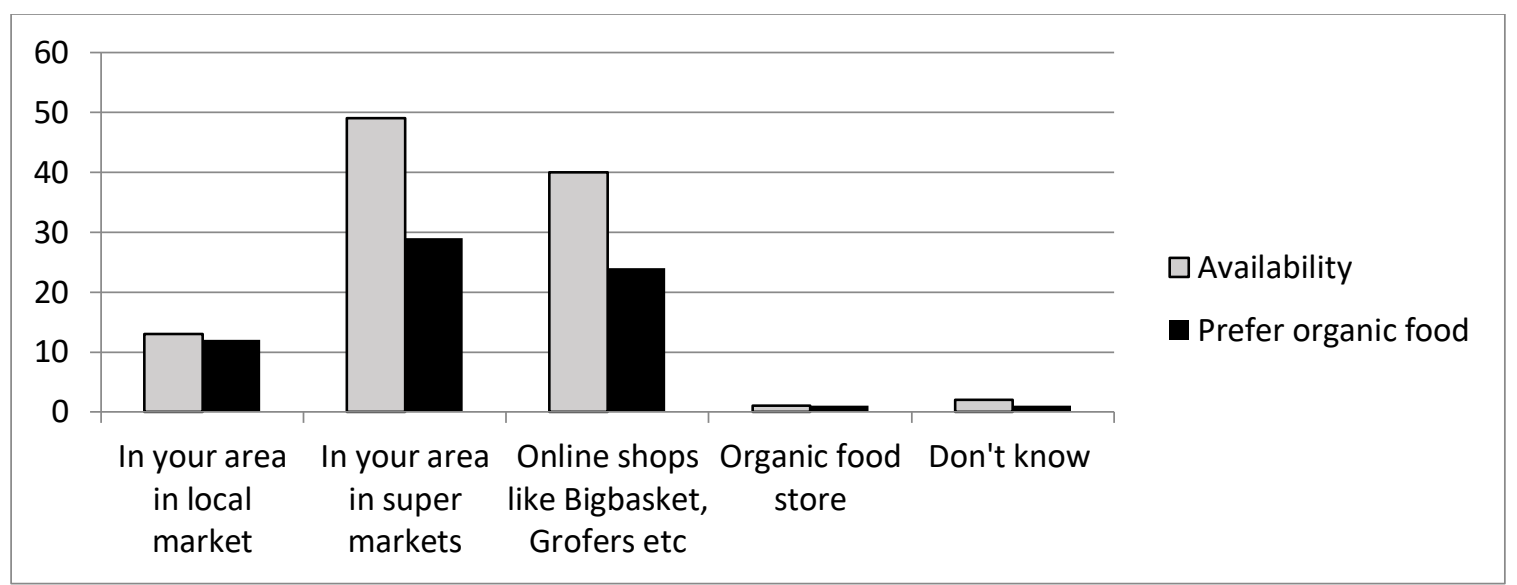

Figure 16: Availability in different stheces and preference of organic food

Table 6: Relation between availability and preference of organic food

\begin{tabular}{|l|l|l|l|}
\hline Places of availability & $\begin{array}{l}\text { Availability in } \\
\text { vicinity }\end{array}$ & $\begin{array}{l}\text { Prefer } \\
\text { organic food }\end{array}$ & $\begin{array}{l}\text { Proportion preferring } \\
\text { organic food }\end{array}$ \\
\hline In the area in local market & 13 & 12 & 0.923 \\
\hline $\begin{array}{l}\text { In the area in super } \\
\text { markets }\end{array}$ & 49 & 29 & 0.591 \\
\hline $\begin{array}{l}\text { Online shops like } \\
\text { Bigbasket, Grofers etc }\end{array}$ & 40 & 24 & 0.6 \\
\hline Organic food store & 1 & 1 & 1 \\
\hline Don't know & 2 & 1 & 0.5 \\
\hline
\end{tabular}

A chi-square test of independence is conducted with the null hypothesis $\mathrm{H}_{010}$ : Availability and preference are independent against alternative hypothesis $\mathrm{H}_{110}$ : They are not independent. The $\mathrm{p}-$ value $=0.0198<0.05$ suggests the rejection of null hypothesis and establishes that availability and preference are not independent.

Let us define $\mathrm{x}=$ Availability of organic food and $\mathrm{y}=$ Preference of organic food. Te scatter diagram of $\mathrm{x}$ and $\mathrm{y}$ is plotted in graph and then try to fit a linear regression.

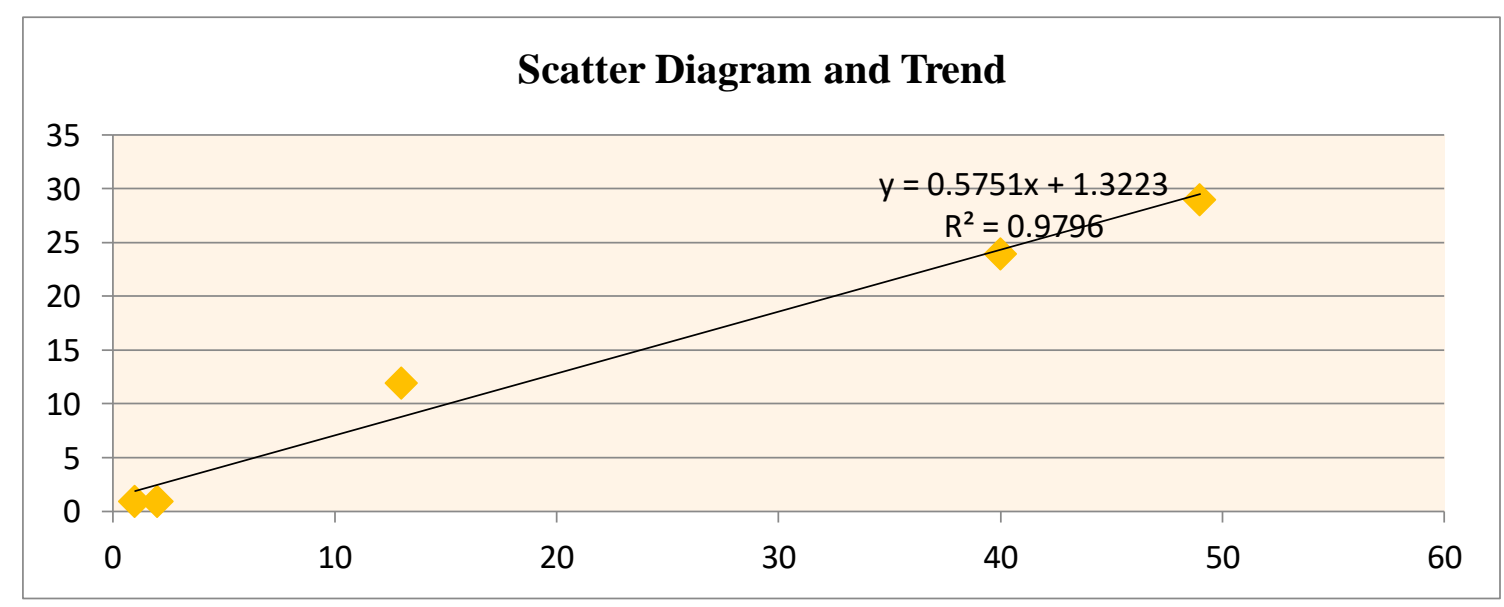

Figure 17: Regression of preference on availability 
The correlation between availability and preference is 0.9897 , which is very high. In addition, the scatter plot exhibited a positive linear trend. Hence linear regression is fitted and the equation of the fitted line is $\mathrm{y}=0.5451 \mathrm{x}+1.3223$. $\mathrm{R}^{2}=0.9796$ which suggests that the fit is good. Also, $\mathrm{p}$ value $=0.00124<0.05$ suggests that the regression coefficient is significant.

Few reasons for which people consume organic food are mentioned in Figure 18. Most of the people prefer because of its benefits brought to health conditions.

\section{Reasons for consuming and not consuming organic food:}

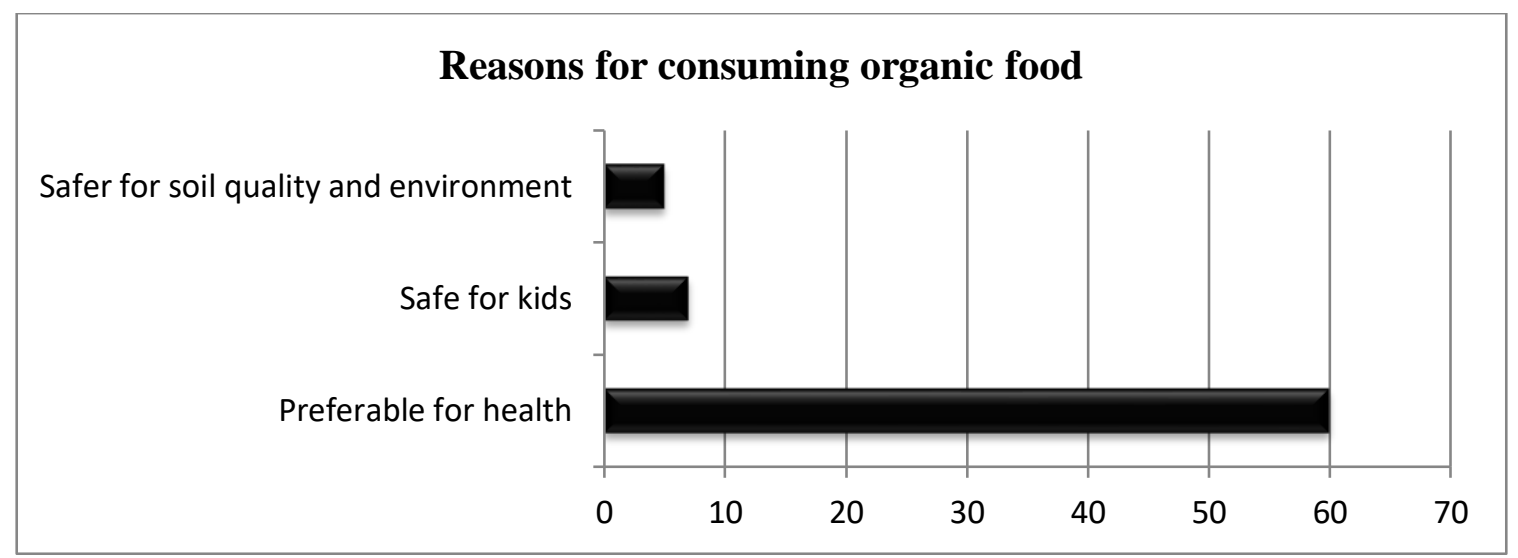

Figure 18: Reasons for consuming organic food

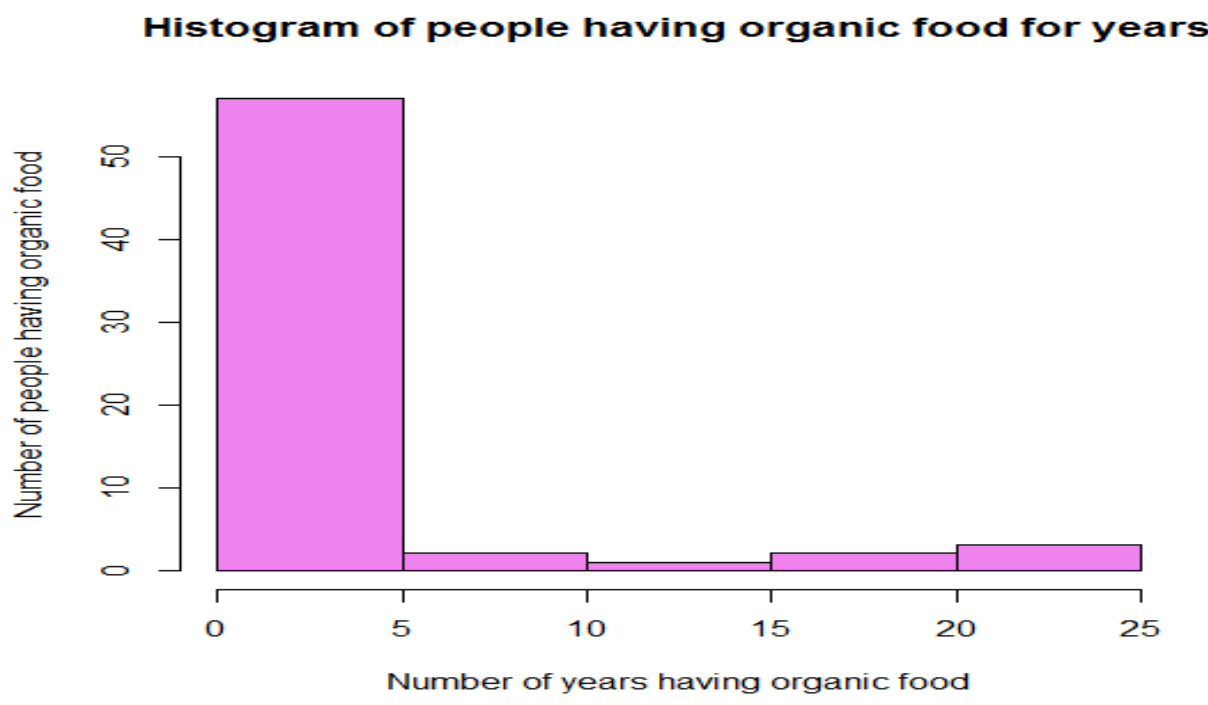

Figure 19: No. of people having organic food for different years

People started to have organic food for about 25 years but most of the people has started very recently in $0-5$ years.

Reasons for not consuming organic food are mentioned in figure 20. Most of the people believe that it cannot be consumed on daily basis as it is costly. 




Figure 20: Reasons for not consuming organic food

Since the most popular reason for not consuming organic food is that it is expensive, so the annual income of those people who had claimed like that were brought under observation and hence the following results.

\section{Income of respondents who said organic food is costly}

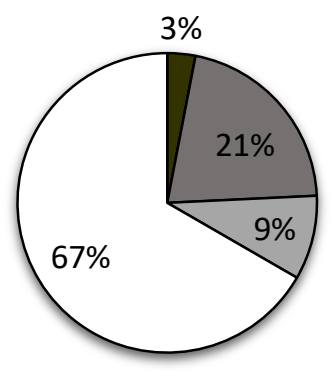

$\square 2$ lakhs- 4 lakhs

$\square 4$ lakhs - 6 lakhs

$\square 6$ lakhs - 8 lakhs

$\square 8$ lakhs and above

Figure 21: Income of those who avoid organic food for its cost

It was found that $3 \%$ belonged to the lowest income group considered in the survey while $67 \%$ belonged to the highest income group. Evidently cost is not the actual reason for people belonging to high income group to avoid consumption of organic food. The reason is something else which is either not stated by them or they simply ignore the goodness of organic food to save money. Whatever be the reason, this outcome is unfortunate.

\section{Limitations of the Study}

- Data on all age-group are not uniformly distributed.

- Data on all occupation are not uniformly distributed.

- Data on all marital status are not uniformly distributed.

- Data on all educational qualification are not uniformly distributed.

- Data on all sex are not uniformly distributed.

- The sample size is small. 


\section{Conclusion}

From the above data interpreted it is evident that the consumption of organic food has raised in last five years, but it should have raised more than what has actually happened. People are well aware of organic food and the benefits driven from it. Consumption of such products will reduce health hazards giving a blissful life. In fact, consumers, irrespective of all age-groups, income and educational qualification have enough knowledge regarding this. But a good number of people are found to ignore this fact and avoid consuming them (organic products). Most of these people have given excuse of such products for being expensive although they themselves belong to high income-group. Consumption also depends on the availability of such products in nearby places. Since life in Bengaluru is very busy, many people do not get ample time to look for organic products if they are not easily available, although there is already a solution to this. Such products can easily be found in the online grocery apps. There are also many people who have included organic food in their diet but have not given up non-organic products either. They prefer both kind of food. According to the survey, such people spend $27 \%$ of their budget on food on an average for organic food and rest on non-organic. Only 17\% of all consumers were found to depend on organic food products totally. In fact, very few people are found to be dependent on such products for more than 10 years.

Advertisements and promotional programs should be conducted to create more awareness about the positive effects of using organic products and consumers should be deliberately disctheaged to consume non-organic food items. Commercial advertisements should be made showing health hazards occurring or may occur due to the harmful manure and chemicals (pesticides, fertilizers, weedicides etc) used for mass production of vegetables and fruits, just in the way outcomes of tobacco are being shown to people in movie theatres. This can be an effective way to motivate the rich and educated part of the society. The products should be made more available to people both easily and economically. If people compare and find that price of non-organic vegetables cheaper than organic ones, automatically they will have developed tendency to move towards non-organic even knowing its bad effects. This is the place where government can play an effective role by reducing the price of organic food. Government can take various measures to promote production, consumption and advertisement of organic products.

\section{References}

[1] Abhang P., Patil M. and Moghe P. (2015). "BENEFICIAL EFFECTS OF AGNIHOTRA ON ENVIRONMENT AND AGRICULTURE", (Book) 5(2).

[2] Basha MB., Shamsudin MF. (2017). "WHAT DRIVES UAE BUYERS TOWARDS ORGANIC FOOD PRODUCT? AN EXPERIMENTAL STUDY", Arabian Journal of Business and Management review, 7(3), 312. https://www.omicsonline.org/open-access/what-drives-uaebuyers-towards-organic-food-product-an-experimental-study-94914.html

[3] Brijesh Sivathanu. (2015). "FACTORS AFFECTING CONSUMER PREFERENCE TOWARDS THE ORGANIC FOOD PURCHASES”, Indian Journal of Science and Technology, Vol 8(33), 1 6.

[4] Dr. Akankshya Patnaik. (2018). "CONSUMERS PERCEPTION TOWARDS ORGANIC FOOD: A STUDY”, JETIR, 5(6), 309-313. http://www.jetir.org/papers/JETIRC006054.pdf.

[5] Dr. H.M. Chandrashekhar. (2014). "CONSUMERS PERCEPTION TOWARDS ORGANIC PRODUCTS-MYSORE CITY", International Journal of Research in Business Studies and Management, 1(1), 52-67. https://www.ijrbsm.org/pdf/v1-i1/7.pdf. 
[6] Gauthami H.S. (2008.) "MARKET RESEARCH ON ORGANIC AGRICULTURAL PRODUCE IN BANGALORE CITY", Department of Food and Nutrition, University of Agricultural Science,1-95. http://krishikosh.egranth.ac.in/bitstream/1/5810021650/1/Th-9218.pdf.

[7] Jagannath D. (2008). "PROSPECTS OF ORGANIC FARMING IN INDIA", Journal of Global Communication, 1(2), 181-193.

[8] K. Renugadevi, Dr. M. Ramya. (2017), "A STUDY ON CONSUMERS ATTITUDE TOWARDS ORGANIC PRODUCTS WITH SPECIAL REFERENCE TO SALEM CITY”, International Journal of Interdisciplinary Research in Arts and Humanities (IJIRAH), 2(2), 160-162.

[9] K. Sundaresh, Dr. S. Babu. (2017), "COIMBATORE COLLEGE STUDENTS'S PERCEPTION AND BUYING INTENETION TOWARDS ORGANIC FOOD PRODUCTS”, Imperial Journal of Interdisciplinary Research (IJIR), 3(7), 472-475. https://www.onlinejournal.in/IJIRV3I7/076.pdf

[10] Konda Kalyani. (2017). "CONSUMER PERCEPTION TOWARDS ORGANIC FOOD PRODUCTS IN INDIA”, IJIRT, 4(7), 1-5. http://ijirt.org/Article?manuscript=145018.

[11] M.Shireehsa, Prof.V.Chandra Sekhar Rao. (2018). “A STUDY ON URBAN CONSUMER PERCEPTION TOWARDS ORGANIC FOOD PRODUCTS”, IOSR Journal of Business and Management (IOSR-JBM), 20(6) (III.), 18-23. http://www.iosrjournals.org/iosrjbm/papers/Vol20-issue6/Version-3/D2006031823.pdf.

[12] Mishra R. (2009). "SCIENTIFIC ROLE OF AGNIHOTRA IN ORGANIC FARMING", 1st Edition, Shri Madhavswami Paryavaran Sanrakshan Samiti, 15-30.

[13] Mr.Pradeep Kumar, Dr.Hema Gulati. (2017). "CUSTOMER'S PERCEPTION TOWARDS ORGANIC PRODUCTS IN RURAL AREA OF HARYANA", International Journal of New Technology and Research (IJNTR), 3(5), 15-20. https://www.ijntr.org/download_data/IJNTR03050074.pdf.

[14] Nayana Sharma, Dr. Ritu Singhvi. (2018). "CONSUMES PERCEPETION AND BEHAVITHE TOWARDS ORGANIC FOOD: A SYSTEMATIC REVIEW OF LITERATURE”, Journal of Pharmacognosy and Phytochemistry, 7(2), 2152-2155. http://www.phytojournal.com/archives/2018/vol7issue2/PartAE/7-2-212-272.pdf.

[15] Potdar J. (1988). "Agnihotra Krishi” (Book).

[16] Priya Soni. (2015). "INDIAN CONSUMER'S ADOPTION OF A GREEN INNOVATION AND SOCIAL IDENTITY-THE CASE OF ORGANIC FOOD.” Journal of commerce, economics \& computer science, 1(4), 1-23.

http://shodhganga.inflibnet.ac.in/bitstream/10603/204402/13/17publication\%20paper.pdf.

[17] S. Suganya, Dr. S. Aravinth. (2014). "ANALYSIS OF CONSUMERS'S PREFRENCE TOWARDS ORGANIC FOOD PRODUCTS BASED ON PRODUCT PRICE”, Journal of Business Management \& Social Sciences Research, 3(12), 73-76.

http://www.borjournals.com/a/index.php/jbmssr/article/viewFile/1907/1237.

[18] Sathyendra Kumar AD, Dr. H. M. Chandrashekar. (2015). "A STUDY ON CONSUMERS BEHAVIOUR TOWARDS ORGANIC FOOD PRODUCTS IN MYSORE CITY”, International Journal of Management Research and Review, 5(11)(5), 1082-1091. http://ijmrr.com/admin/upload_data/journal_Satyendra\%20\%20\%205nov15mrr.pdf.

[19] Sofia P.K., Prasad R. and Vijay V.K. (2006). "ORGANIC FARMING-TRADITION REINVENTED”, Indian journal of traditional knowledge,5(1), 139-142.

http://www.niscair.res.in/ScienceCommunication/ResearchJournals/rejour/ijtk/Fulltextsearch/200 6/January\%202006/IJTK-Vol\%205(1)-January\%202006-pp\%20139-142.html.

[20] Soumya. K.M. (2015). "ORGANIC FARMING: AN EFFECTIVE WAY TO PROMOTE SUSTAINABLE DEVELOPMENT IN INDIA", IOSR Journal of Humanities and Social Science (IOSR-JHSS), 20(6), 31-36. http://www.iosrjournals.org/iosr-jhss/papers/Vol20-issue6/Version4/G020643136.pdf.

[21] Vishal Kumar Laheri, Purushottam Kumar Arya. (2015). "A STUDY ON CONSUMER DECISION TOWARDS PURCHASE OF ORGANIC FOOD PRODUCTS: A CASE STUDY OF DELHI", Indian Journal of Commerce \& Management Studies, 6(2), 84-87. 
http://www.scholarshub.net/ijcms/vol6/issue2/Paper_13.pdf.

[22] www.apeda.gov.in

*Corresponding author.

E-mail address: anisam87@ gmail.com 